\title{
THE FEBRUARY REVOLUTION OF 1917 AND UKRAINIAN OFFICERS: THE CHOISE OF POLITICAL ORIENTATION
}

\author{
Roman Tiutenko \\ Ivan Franko National University of Lviv \\ 1 Universytetska str., Lviv, Ukraine, 79000 \\ tyutenko.roman20@gmail.com
}

\begin{abstract}
The article is devoted to social and political moods of Ukrainian officers in the Russian imperial army in Ukraine. It shows the conditions of their condition at the fronts of the First World War on the eve of the February revolution of 1917.

An attempt was made to ascertain the political position of Ukrainian officers, their moods, behavior, social and political attitudes in the period of revolutionary events in Ukraine in 1917 and in the first months of establishment of the Ukrainian statehood. The article shows the personal officer's attitude to the change of the political system and the attention is focused on the problem of choosing their political path.
\end{abstract}

Keywords: the February revolution, Ukraine, Russian Empire, officers, political orientation, the Ukrainian Central Council.

\section{Introduction}

During the First World War on the territory of the Ukrainian lands were Russian army, which as a result of the February revolution of 1917 became a powerful centre for democratic and national liberation movement. A certain percentage of the personnel of the Russian army were Ukrainian officers. They were actively included in the revolutionary process, which covered the Ukrainian society after the overthrow of the Russian autocracy and quickly became a separate element of national military movement. Officers had one of the leading roles in the Ukrainian people's fight for the statehood, because it had brightly pronounced state character, which occupied an important place in the process of national revival of Ukraine.

\section{Analysis of researches and publications}

The problems of social and political moods of Ukrainian officers during the February revolution are not fully disclosed and represented in fragmentary mentions in the works of Ukrainian authors. To this theme a few authors have been approached in different aspects: author [1], in particular concerning on the first steps in the military building in Ukraine, author [2] wrote on the some aspects of relations between Ukrainian officers and government, author [3] particularly with regard to the February revolution events at the front, author [4] wrote on the influence of the February revolution regarding the officers.

However, as I remarked, in Ukrainian historiography the specified issue was not a separate object. Therefore memories by authors [5-7] and others officers, that were written during the Ukrainian revolution 1917-1921, are an important source for illustration of these issues. As well as materials from the Central state historical archive in Kyiv, in Lviv, and the State archive of the Lviv region.

\section{Aim and objectives of the research}

The goal of this study is an attempt to outline the situation of Ukrainian officers before and during the February revolution of 1917, the influence of the February revolution of 1917. Moreover, the tasks in this article are focused on the highlighting social behaviour, psychology, personal moods and choice of political orientation of Ukrainian officers against the background of the revolutionary events in Ukraine through their memoirs.

\section{Results of research}

With the outbreak of the First World War, on the territory of Ukrainian lands laid South-Western front - one of the largest fronts of the Russian army, as well as a small part of Romanian front. The composition of South-Western front consisted of 7, 8, 11 and a Separate 
army. As of March 1, 1917, its personnel were 2 million 281 thousand soldiers, officers and military officials. The Ukrainians in it were $1 / 3$, and on the Romanian front $1 / 4$ of its staff. All non-Russian contingents on these fronts were $65 \%$ [1].

In general, in the Russian army at the beginning of 1917 were 6 million 798 thousand soldiers, and those who were in spare parts -2 million 260 thousand. Ukrainians was approximately 3,5 million of this composition. As you can see, the Russian army almost $40 \%$ consisted of the Ukrainians [1]. However, only a small percentage of officers belonged to the higher officers, that is, before the generals. The middle and lower ranks, which included the Ukrainians, were the basis of the officer corps of the Russian imperial army.

Events at the front in early 1917 were unfolding not in favor of the Russian Empire and its army. There has been fraternizing with the enemy and defections that have undermined, and so weakened the army and threatened to the state. Those events were brightly highlighted in the memoirs by officers, members and contemporaries of the time. Therefore in the army there had been indiscipline: in officer's memory flashed images of the first days of the mobilization of 1914 and the "masses of soldiers on active service and in reserve which in the rows went to the front", Colonel Mykola Galagan remembered [5].

Ukrainian Colonel Volodymyr Kedrovskyi pointed out that the situation at the front was complex, the food was getting worse every day, and silent protest grew among the officers [6]. Besides, General V. Petriv recalled in his "Memoirs" ("Spohady"):

"The whole load based itself on them, on their lives and their health, and reverberation of political struggle that went on in political centres for power, forced the officers to ponder over who is to blame for all those failures and wasting their lives and come to conclusions only negative about the existing order, higher headquarters, and managing leadership" [8].

A centurion ("sotnyk") of the Ukrainian People's Republic Army Nykyfor Avramenko with this in mind noted that "in the infantry there was a gap and it has become a little dimmed" [7]. And soon mostly junior officers "almost openly expressed their views, in solidarity with the soldier: when will the war end?" [7].

Moreover, among the lower officer ranks in January-February, 1917, according to the reports of the head of Volyn provincial gendarmerie management, the spread of illegal organ "the Soldier's journal" ("Soldatskiy Viestnik"), which reported on strikes and massacres in the Empire, took place [9]. Therefore, the attitude of the regimental commanders and other officers until the abdication of emperor Nicholas II was mostly calm, and as noted by General Vladimir Selivachev, some even said directly: "We even knew and were expecting" [10].

The orders about the renunciation of the Imperial family and the events in Petrograd were received by the troops of the South-Western front very late. In particular, about this Colonel M. Galagan, mentioned:

"Life went past the orders, but the revolution has carried out its aims and objectives, ahead of various official messages that passed all stages of the long military hierarchy and very late reached the bottom and efficient army" [5].

But the officers felt that something had happened. For example, V. Kedrovskyi said about this: "it is clear that in Petrograd there was something extraordinary. But why we, the army, don't know anything?" [6]. And in spite of this, "there would be no doubt that within a few days the whole front learns about the coup, because to hide such an event, of course, nobody can" M. Galagan considered [5].

The news about the abdication of the Emperor Nicholas II from the throne a significant portion of officers embraced with great joy. Colonel V. Kedrovskyi focused on the first officer's impression from concerning Emperor's abdication. In this case he reflected on pages of memoires:

"Finally brought the Newspapers...Hands are shaking, turning its.....True!...we are reading the tenth time of the last Manifesto of Nicholas II and tears of joy fill my eyes...Something comes up in my throat and pressure in it...I want to run on the street to congratulate all with the holiday of freedom...dreams come True!" [6].

Nevertheless, soon the revolutionary movement has penetrated different layers of the Ukrainian society, in particular the officers and the whole Army. As was mentioned by Volodymyr 
Simiantsev in his memoirs "the Years of the Cossacks" ("Roky kozakuvannia") - "Ukraine was raging all around" [11].

The revolutionary moods spread on the army and it influenced very negative. The cases of desertion were oftentimes, which eventually became a mass phenomenon on the front [12]. Thus, in particular General Mikhail Alekseev wrote to the War Minister Alexei Guchkov: "the armies of the South-Western and Romanian fronts only with advanced positions at the same time (1-7 April 1917) 347 soldiers deserted" [4]. Every day discipline has been falling, and culprits of a breach of military duty, treated to possible punishments with complete indifference. Therefore, this has led to the weakening of the authority of officers and managers. Some officers were removed from power over their subordinates, and the power in the front regiments was placed under the control of soldiers committees. To restore damaged credibility and to resolve the increasingly growing contradiction was impossible. Consequently, among the officers, their morale was falling more and more [12].

During the chaos and disintegration of the army, the Russians more fell under the revolutionary and anarchist influence. Therefore they have been losing morale, but the Ukrainians at that time were more stable, and there was a definite Ukrainians officer's demarcation from Russian officers. As Colonel Volodymyr Savchenko considered: "now not only Ukrainian officers, but even ordinary soldiers, looked with disdain on their Moscow comrades" [13].

In the early days of the revolution, Germany was actively engaged in propaganda, both in the rear, through its spies, and on the front under the guise of local truces and fraternization. As a result, the soldiers no longer eager to fight, to "prove, as a Russian citizen defends his free Russia" [4] and the officers no longer advocated a war to win.

After the fall of the monarchy, the officers began to gather meetings about how to proceed further. And among them was the uncertainty about whether right if they were going without permission of senior management, and aren't they violating the discipline. Subsequently, however, junior officers, mostly ensigns, who welcomed the fall of the autocracy, became democratically minded and were ready to support a democratic system in the state and the army.

Gradually in the attitudes of soldiers and officers had been a great change. The warriors are already without the slightest fear widely used the rights of free citizens. Already none thought about the illegal meetings or the illegality of the committees, as it was at the beginning of the revolution. On the contrary, it was commonplace, sanctioned and confirmed by corresponding official acts.

In general, after the February revolution of 1917, the officers were divided into two categories. On the one hand, most of them declared themselves to be Democrats. It mainly consisted of non-staff officers. The small part of the staff officers also joined it after the revolution, - said M. Galagan, "began to adapt for military mass - walked on their hind legs" [5]. On the other hand, the second part of cadre officers was in opposition to the institution of new orders in the army, seeing in it the lowering of their situation. In particular, personnel officers negatively turned against the military Minister, Alexander Guchkov, who issued the Order No. 1 on 1 (14) March 1917. According to that order, the weapon in the military parts should be under the control of company soldier and battalion committees and in no case can be issued to officers. Besides, the order gave civil rights to the soldiers, put them on an equal footing with officers outside the service. It cancelled bestowal of honour, titles of officers and generals. Officers should respectfully refer to the soldiers and greet them by the hand [14].

This order provoked an outrage and concern in the staffs of the armies of the South-Western front, and in the headquarters. The staffs quickly announced that decree the fiction and the trick by the attackers and threatened with punishment all those who were spreading it. For example, on 6 March, the staff of VII army published its order, stating:

"According to special announcement by the Minister of justice Kerensky and Chairman of the Board of deputies, the order of this is pure fiction and is distributed by evil persons who nothing to do with the government and the Board of deputies do not have...in the case of appearance this order immediately to convey. Persons, who try to spread the orders, to arrest" [3].

However, the spontaneous revolutionary movement of the Ukrainian officers could easily gain the character of the ruins and the mess, as not all officers were willing to support the new democratic system in the state and the army. However, as pointed out by M. Galagan, there was a 
small organized part of the army, which under the leadership of the adherents of the old Imperial order, who were officers of higher ranks, could master the situation and return everything to its previous state. There existed a certain amount of military who didn't want to change the order in the state. M. Galagan remembered:

"I told colonel...about the revolutionary events and asked to give the appropriate orders. The colonel began to prove to me that Russia "not a single day can exist without the Emperor" [5].

But not all ventured on a decisive step against the revolution.

With the formation of the first government in Ukraine - the Ukrainian Central Council ("Ukrainska Tsentralna Rada"), officers of the highest rank had adopted a new system of government, the new Ukrainian government; however, they feared that they would be relieved of command. Thus, as colonel M. Chebotariv wrote:

"It were all old people in high ranks...they All spoke Russian, they apologized that do not know their native language, because, they said, "You know that we all learned in Russian, etc., but at the same time they assured in their greatest loyalty to the Ukrainian authorities, they urged that they will try to know their native language. They were afraid to be removed from places they occupied" [15].

In the memoirs, M. Galagan states that among the military there were many energetic individuals in whom quickly evolved just "Ukrainian spontaneity of the senses" ("ukrainska stychiynist' chuttia") and mental consciousness of the belonging to Ukrainian nationality. Thus, M. Galagan reflected: "among the last i recall one outstanding officer, company sergeant. Once speaking with him, asked him, when he became Ukrainian. He, smiling, replied: "You last year said that I had a moustache of the Cossack-Zaporozhets". I really Zaporozhian Cossack; I am from the Katerynoslav region - right from the Zaporozhian host. It turns out I have long been Ukrainian!" [5]. So, again, in these memoirs, that very often mentioned "Ukrainian song was heard everywhere, and the Russians also sang Ukrainian songs, often horribly mangling Ukrainian words. All the warriors - Ukrainians have been speaking among themselves "differently" - in Ukrainian - and it was considered normal. Sometimes elders, adapting to it, in the relations between themselves and soldiers of the Ukrainian language used this language or some expressions, not even noticing deviation from ascription to use of the Russian language" [5].

On 9 March 1917 the Ukrainian Central Council issued a proclamation "To the Ukrainian people", where called on the peasants, workers, soldiers and intellectuals to remain calm, to join political, cultural, economic unions and associations. Ukrainian officers were among the first who responded to that appeal. On the same day at a meeting of the officers and soldiers of the Kyiv garrison town organized the Ukrainian Constituent Military Council headed by Colonel Mykhailo Glynskyi, who demanded from the Temporary government of Russia "will make to Ukraine even before the Constituent Assembly the same legal act that has already been published for Finland and confirm for the Ukrainian People all rights and liberties" [2].

At the same time was formed the Officers trade Union headed by Colonel Leonid Novosyltsev, who defended the professional interests of officers. The Union opposed the Temporary government of Russia because it considered its power from the Ukrainian Central Council [8]. However, not all officers first recognized the Central Council. In particular, in March 1917 in Kyiv was established the all-Russian military Union, which in its appeal to soldiers at the beginning of April 1917, recognized that "the Provisional government, to the convocation of the constituent Assembly, is the only legitimate and responsible executor of the will of Russia" [16].

Subsequently, a junior and part of senior officers supported the Ukrainian Central Council in its first steps, for they hoped to create a strong state and army. It is evidenced by the congratulations, which were received in the spring of 1917 from a variety of military units, formations and front. They were especially numerous in April 1917, after the Ukrainian National Congress, which the Ukrainian Central Council was recognized as a representative body of the Ukrainian people. In particular, the 4 officers of the cavalry division wrote that they were "waiting for a democratic Republic, independent Free Ukraine" [17]. At the same time, the military garrison of Kremianets sent a telegram, which stated that at the meeting "accepted very much to welcome the Council in a new composition and support it by all means for the aspirations of national-territorial autonomy of Ukraine" [18]. 
The Ukrainian Central Council, considering the deployment of the Ukrainian movement in the army, paid some attention to military affairs. It formed a military commission to coordinate actions of the Ukrainian military movement, which announced the convening of the First allUkrainian military Congress on May 5, 1917. The key point of the Congress was that the officers supported the Ukrainian government and has recognized the Ukrainian Central Council as the only competent body called upon to resolve all matters relating to the Ukraine [19]. The second allUkrainian military Congress on June 17, 1917 also announced that will provide active and strong support of the Central Council in all its activities, and appealed the Ukrainian people to comply strictly with its regulations [20].

\section{Discussion of the results}

The proposed theme of research, particularly with regard officer's political orientation during the the February Revolution of 1917, distinguishes the new aspect of the life and daily life of Ukrainian officers within the Revolution of 1917-1921 on the Ukrainian lands.

The received results continue the scholarly direction of research in the sphere of officer's image, especially in the issues of social behavior and social transformation due to the February Revolution of 1917.

It is necessary to notice, that the investigated problems with regard to the social and political challenges, moods will be useful for complement of Ukrainian stratum's participation in the state building of Ukrainian People's Republic against the backdrop of the revolutionary processes in Ukraine in 1917.

\section{Conclusions}

To sum up the above discussion, it needs to be stressed that events at the front in late 1916 early 1917 unfolded not in favor of the Russian army, so gradually the officers were beginning to experience the inevitable changes. At that time Ukrainian officers anticipated the approach of some transforms in the country. Therefore, officer's relation to the abdication of Emperor Nicholas II and the fall of autocracy in the Russian empire were largely peaceful.

However, the explosion of the February revolution of 1917 brought chaos in the empire and at the front. As a result, the former Russian army suffered demoralization and was in disintegration. Officers who lost power had to elect a political way: to support the Ukrainian government, the newly formed the Ukrainian Central Council, or to obey the Provisional government of Russia.

Ukrainian officers after the February revolution of 1917 were divided into two categories. Most of them declared themselves to be democrats. The base was not regular officers, who were prepared to support a democratic system in the state and the army. The second part of cadre officers was in opposition to the installation of new system in the army, to the Charter changes, seeing in it a lowering of their status. Advantage won the first category, particularly young Ukrainian officers who reacted positively to the fall of autocracy in Russia and support the Ukrainian Central Council. They tied their hopes with the creation of the Ukrainian state, and national army.

In general, the political views of politicians of Central Council and Ukrainian officers coincided. They saw the future state structure of the former Russian Empire as a Federal democratic Republic, in which Ukraine should be a standalone unit.

\section{References}

[1] Holubko, V. (1997). Armija Ukrajinskoji Narodnoji Respubliky 1917-1918. Utvorennja ta borotba za derzhavu. Lviv: Kalvarija, 275.

[2] Verstiuk, V. (2007). Ukrajinska Centralna Rada i armija. Vojenna istorija, 1-3. Available at: http://warhistory.ukrlife.org/1_3_07_2.htm

[3] Holub, P. (1958). Soldatskie massy Juho-Zapadnoho fronta v borbe za vlast Sovetov (mart 1917 h. fevral 1918 h.). Kyiv: Gospolitizdat USSR, 254.

[4] Bazanov, S. (2010). Antivoennyje vystuplenyja na russkom fronte v $1917 \mathrm{~h}$. hlazamy sovremennikov (vospomynanyja, dokumenty, kommentaryy). Moscow, 363. 
[5] Galagan, M. (2005). Z mojih spomyniv (1880-ti - 1920 r.). Kyiv: Tempora, 656.

[6] Kedrovskyj, V. (1967). 1917 rik. Vinnipeg: Tryzub, 526.

[7] Avramenko, N. (2007). Spomyny zaporozhtsya. Kyiv: Tempora, 456.

[8] Petriv, V. (1927). Spomyny z chasiv ukrajinskoji revoljuciji (1917-1921). Chastyna I: Do Berestejskoho myru. Lviv, 180.

[9] Centralnyj derzhavnyj istorychnyj archiv Ukrajiny, m. Kyiv, F. 1599, Op. 1, Spr. 278, Ark. $85-86$.

[10] Kakurin, N. (1925). Iz dnevnyka hen. V. Y. Selivacheva. Krasnyj archiv, 2 (9), 104-131.

[11] Simjancev, V. (1976). Roky kozakuvannja. 1917-1923 (Spohady). Filadelfija, 399.

[12] Derzhavnyj archiv Lvivskoji oblasti, F. 905, Op. 1, Spr. 207, Ark. 10.

[13] Savchenko, V. (1935). Spohady pro ukrajinskyj rux u XII rosijskij armiji u 1917 roci, Za derzhavnist. Materijaly do istoriji vijska ukrajinskoho, 1, 53-65.

[14] Hryckevich, A. (2011). Borba za Ukrainu. 1917-1921. Minsk, 528.

[15] Chebotariv, M. (2003). Vyzvolni zmahannja ochyma kontrrozvidnyka. (Dokumentalna spadshchyna Mykoly Chebotariva). Kyiv: Tempora, 288.

[16] Centralnyj derzhavnyj istorychnyj archiv Ukrajiny, m. Kyiv, F. 315, Op. 2, Spr. 734, Ark. 69.

[17] Z armij (1917). Nova Rada, 22, 2.

[18] Z Kremencja (1917). Nova Rada, 22, 2.

[19] Shandruk, P. (1932). Armija UNR ta jiji borotba za derzhavnist. Hurtujmosja, 4, 8.

[20] Centralnyj derzhavnyj istorychnyj archiv Ukrajiny u Lvovi, F. 760, Op. 1, Spr. 4, Ark. 28. 